\title{
Analysis of Family Resilience: The Effects of the COVID-19
}

\author{
Dony Darma Sagita, ${ }^{1}$ Mutiara \\ Felicita Amsal, ${ }^{2}$ Shafna Utami \\ Nur Fairuz ${ }^{3}$ \\ ${ }^{1}$ Universitas Muhammadiyah Prof. DR. \\ HAMKA Semarang-Indonesia, \\ Universitas Negeri Padang, Padang- \\ Indonesia, ${ }^{3}$ Universitas Negeri Malang, \\ Malang-Indonesia
}

Corresponding Author: Dony Darma Sagita, email: donyds@uhamka.ac.id, Jl. Limau II, Jakarta Selatan 12130, Indonesia

\begin{abstract}
This study aims to analyze family resilience during the COVID-19 pandemic. The COVID-19 pandemic is a worldwide health problem at this time, including Indonesia, with a massive spread. Various issues arise due to the COVID-19 pandemic in economic, social, cultural, educational, and social welfare. This research was conducted on the people who lived in the COVID-19 red zone at Jabodetabek (Jakarta, Bogor, Depok, Tangerang, and Bekasi) area, with a total sample of 311 people. This study's data are political data collected using the Family Resilience instrument distributed using the Google Form application and data analysis using the Rasch Model and SPSS. Based on the research, it was found that the level of family resilience during the COVID-19 pandemic was in a suitable category. Therefore, it is necessary to increase parents' understanding in maintaining harmony and stability in the family conditions.
\end{abstract}

Keywords: family resilience; Rasch Model; COVID-19

\begin{abstract}
Abstrak: Penelitian ini bertujuan untuk menganalisis ketahanan keluarga selama pandemi COVID-19. Pandemi COVID-19 menjadi permasalahan kesehatan seluruh dunia pada saat ini, termasuk Indonesia dengan tingkat penyebaran yang masif. Berbagai permasalahan muncul sebagai efek dari pandemi COVID-19, baik dari segi ekonomi, sosial, budaya, pendidikan dan kesejahteraan masyarakat. Penelitian ini dilakukan kepada masyarakat yang bearada dikawasan zona merah COVID-19 daerah jabodetabek, dengan jumlah sampel 311 orang. Data dalam penelitian ini adalah data politomi yang dikumpulkan dengan menggunakan instrument Family Resilience yang disebarkan menggunakan aplikasi Google Form dan analisis data menggunakan Rasch Model dan SPSS. Berdasarkan penelitian didapat hasil tingkat ketahanan keluarga selama pandemi COVID-19 pada kategori cukup. Sehingga, perlu adanya peningkatan pemahaman orangtua dalam mejaga keharmonisan dan ketahanan di dalam keluarga.
\end{abstract}

Kata Kunci: Ketahanan keluarga; Rasch Model; COVID-19 


\section{A. Introduction}

COVID-19 pandemic is a global health problem today. This pandemic is a new virus that originated in Wuhan, China. ${ }^{1}$ COVID-19 was designated as a pandemic by WHO in the early 2020s. This virus's spread can spread through saliva or duplex, caused by people who are positively infected by this virus when talking, coughing, and sneezing. ${ }^{2}$ The increase in these cases continues quickly and significantly; even during March, there was an increase of $69.17 \%{ }^{3}$ A vaccine for treatment has not been found, ${ }^{4}$ causing problems for the community of the dangers of this virus, including Indonesia.

The World Health Organization and countries in the world only commit social restrictions with physical distancing, health protocols, etc., which ultimately also lead to the strengthening of each individual's antibodies in the face of COVID-19.5 Confusion is rife everywhere, between those who comply

\footnotetext{
${ }^{1}$ Dawei Wang et al., "Clinical Characteristics of 138 Hospitalized Patients With 2019 Novel Coronavirus-Infected Pneumonia in Wuhan, China," JAMA 323, no. 11 (2020): 1061, https:// doi.org/10.1001/jama.2020.1585; Chih-Cheng Lai et al., "Severe Acute Respiratory Syndrome Coronavirus 2 (SARS-CoV-2) and Coronavirus Disease-2019 (COVID-19): The Epidemic and the Challenges," International Journal of Antimicrobial Agents 55, no. 3 (2020): 105924, https:// doi.org/10.1016/j.jiantimicag.2020.105924; Nur Sholikah Putri Suni, "Kesiapsiagaan Indonesia Menghadapi Potensi Penyebaran Corona," Pusat Penelitian Badan Keahlian DPR RI, 2020, http://sdip.dpr.go.id/search/detail/category/Info Singkat/id/1033; Novia Andansari Putri Restuningdyah and Emmy Amalia, "Pemeriksaan CT-SCAN Thorax pada Kasus COVID-19 di Provinsi Nusa Tenggara Barat," Jurnal Pengabdian Magister IPA 3, no. 1 (2020): 1-4, https://doi.org/ 10.29303/jpmpi.v3i1.447.

${ }^{2}$ World Health Organization, "WHO Director-General's Opening Remarks at the Media Briefing on COVID-19-11 March 2020," Geneva, Switzerland, 2020, https://www.who.int/directorgeneral/speeches/detail/who-director-general-s-opening-remarks-at-the-media-briefing-on-covid19---11-march-2020; Soumen Sadhu et al., "COVID-19: Limiting the Risks for Eye Care Professionals," Ocular Immunology and Inflammation 28, no. 5 (2020): 714-20, https://doi.org/ 10.1080/09273948.2020.1755442; Gedif Meseret Abebe, "Emerging and Re-Emerging Viral Diseases: The Case of Coronavirus Disease-19 (COVID-19)," International Journal of Virology and AIDS 7 (2020): 067, https://doi.org/10.23937/2469-567X/1510067.

${ }^{3}$ Ritesh Bhat et al., "COVID 2019 Outbreak: The Disappointment in Indian Teachers," Asian Journal of Psychiatry 50 (2020): 102047, https://doi.org/10.1016/j.ajp.2020.102047.

${ }^{4}$ Mohamed E El Zowalaty and Josef D Järhult, "From SARS to COVID-19: A Previously Unknown SARS- Related Coronavirus (SARS-CoV-2) of Pandemic Potential Infecting Humans - Call for a One Health Approach," One Health 9 (2020): 100124, https://doi.org/10.1016/ j.onehlt2020.100124; Nany Hairunisa and Husnun Amalia, "Review: Penyakit Virus Corona Baru 2019 (COVID-19)," Jurnal Biomedika dan Kesehatan 3, no. 2 (2020): 90-100, https://doi.org/ 10.18051/JBiomedKes.2020.v3.90-100; Nugroho Susanto, "Pengaruh Virus COVID-19 terhadap Bidang Olah Raga di Indonesia," Jurnal Stamina 3, no. 3 (2020): 145-53, https://doi.org/ 10.24036/jst.v3i3.491.

5World Health Organization, "WHO Director-General's Opening Remarks at the Media Briefing on COVID-19-11 March 2020."
} 
with the health protocol or those who ignore it, and so on. The search for treatment and treatment of Corona Virus has become a severe event and is needed by the world community today.

COVID-19 in Indonesia is increasing and expanding across regions and countries, accompanied by the number of cases and deaths. ${ }^{6}$ This increase impacts the political 7 , economic, ${ }^{8}$ social, cultural, defense, and security aspects and the welfare of the people in Indonesia, so it is necessary to accelerate the handling of COVID-19 in the form of Large-Scale Social Restrictions to reduce the widespread of COVID-19.9 These actions include restrictions on certain activities of the population in an area suspected of being infected with COVID19, including limitations on the movement of people and goods for one particular province or district/city to prevent the spread of COVID-19. The restrictions are carried out through the consolation of schools and workplaces, rules on religious activities, and restrictions on activities in public places or facilities. All of this is contained in Government Regulation number 21 of 2020 concerning Large-scale social conditions implemented in almost every region in Indonesia. ${ }^{10}$

Implementing these large-scale social restrictions has various impacts on Indonesian people's lives both from social, economic, cultural, defense, security, welfare, and community happiness aspects. Besides, it has also been studied

\footnotetext{
${ }^{6}$ Muh Hasrul, "Aspek Hukum Pemberlakuan Pembatasan Sosial Berskala Besar (PSBB) dalam Rangka Penanganan Corona Virus Disease 2019 (COVID-19),” Legislatif3, no. 2 (2020): 385-98.

${ }^{7}$ Aknolt Kristian Pakpahan, “COVID-19 dan Implikasi bagi Usaha Mikro, Kecil, dan Menengah," Jurnal Ilmiah Hubungan Internasional 16, no. 1 (2020): 59-64, https://doi.org/10.26593/jihi. v0i0.3870.59-64.

${ }^{8}$ Nur Rohim Yunus and Annissa Rezki, "Kebijakan Pemberlakuan Lock Down sebagai Antisipasi Penyebaran Corona Virus COVID-19," Salam: Jurnal Sosial dan Budaya Syar'i 7, no. 3 (2020): 227-38, https://doi.org/10.15408/sjsbs.v7i3.15083; Wibowo Hadiwardoyo, "Kerugian Ekonomi Nasional Akibat Pandemi COVID-19," Baskara Journal of Business and Enterpreneurship 2, no. 2 (2020): 83-92, https://doi.org/10.24853/baskara.2.2.83-92; Theresia Vania Radhitya, Nunung Nurwati, and Maulana Irfan, "Dampak Pandemi COVID-19 terhadap Kekerasan dalam Rumah Tangga," Jurnal Kolaborasi Resolusi Konflik 2, no. 2 (2020): 111-19, https://doi.org/10.24198/ jkrk.v2i2.29119.

${ }^{9}$ Yusak Alvian and Steven Laudry, "Propaganda COVID-19 terhadap Awareness Masyarakat Surabaya untuk Mengikuti Program Kerja Pemerintah,” Jurnal Komunikasi Profesional 4, no. 1 (2020): 27-41, https://doi.org/10.25139/jkp.v4i1.2569.

${ }^{10}$ Devina Halim, “Rp 72 Miliar untuk Influencer dalam Atasi Dampak Virus Corona, Pengamat: Mau Diapain?” (Kompas, March 2, 2020), https://nasional.kompas.com/read/2020/03/02/ 10323441/rp-72-miliar-untuk-influencer-dalam-atasi-dampak-virus-corona-pengamatmau?page=all.
} 
from various perspectives that the isolation protocol impacts lifestyle and communication, ${ }^{11}$ physical and mental health, ${ }^{12}$ public health and the environment ${ }^{13}$ and even social relations problems. ${ }^{14}$ Upward of one-third of families have reported feeling very anxious about family stress from COVID-19.15 The impact of isolation is associated with disturbances, such as stress, fear, sadness, anxiety, and emotional disorders on family life. ${ }^{16}$ Likewise with community life at home, with the existence of large-scale social restrictions, an opportunity for families to strengthen ties in the family, because the function of the family during this pandemic is essential in the protection and defense of each family member. In addition to encouraging adjustments to new habits, building new connections and achieving a new identity. The emotions that exist in the family will affect the pressure that arises on that family ${ }^{17}$ and related to family resilience as well as psychological. ${ }^{18}$ However, research reveals that there have been increasing domestic violence cases, ${ }^{19}$ lack of personal space in the family,

\footnotetext{
${ }^{11}$ Jeratallah Aram Dani and Yogi Mediantara, "COVID-19 dan Perubahan Komunikasi Sosial," Persepsi: Communication Journal 3, no. 1 (2020): 94-102, https://doi.org/10.30596/persepsi. v3i1.4510.

${ }^{12}$ Jia Jia Liu et al., "Mental Health Considerations for Children Quarantined Because of COVID19," The Lancet Child \& Adolescent Health 4, no. 5 (2020): 347-49, https://doi.org/10.1016/S23524642(20)30096-1; Cyrus Sh Ho, Cornelia Yi Chee, and Roger Cm Ho, "Mental Health Strategies to Combat the Psychological Impact of COVID-19 Beyond Paranoia and Panic," Annals of the Academy of Medicine, Singapore 49, no. 3 (2020): 155-60.

${ }^{13} \mathrm{Lu}$ Dong and Jennifer Bouey, "Public Mental Health Crisis during COVID-19 Pandemic, China," Emerging Infectious Diseases 26, no. 7 (2020): 1616-18, https://doi.org/10.3201/ eid2607.202407.

${ }^{14}$ Yuta Tanoue et al., "Mental Health of Family, Friends, and Co-Workers of COVID-19 Patients in Japan," Psychiatry Research 291 (2020): 113067, https://doi.org/10.1016/j.psychres. 2020.113067.

${ }^{15}$ Statistics Canada, “Canadian Perspectives Survey Series 1: Impacts of COVID-19” (Canada, April 8, 2020), https://www150.statcan.gc.ca/n1/daily-quotidien/200408/dq200408c-eng.htm.

${ }^{16} \mathrm{Mi}-$ Kyung Yoon et al., "System Effectiveness of Detection, Brief Intervention and Refer to Treatment for the People with Post-Traumatic Emotional Distress by MERS: A Case Report of Community-Based Proactive Intervention in South Korea," International Journal of Mental Health Systems 10, no. 1 (2016): 51, https://doi.org/10.1186/s13033-016-0083-5.

${ }^{17}$ Susan Folkman and Judith Tedlie Moskowitz, "Positive Affect and the Other Side of Coping," American Psychologist 55, no. 6 (2000): 647-54, https://doi.org/10.1037/0003-066X.55.6.647.

${ }^{18} \mathrm{Glenn}$ Affleck and Howard Tennen, "Construing Benefits from Adversity: Adaptotional Significance and Dispositional Underpinnings," Journal of Personality 64, no. 4 (1996): 899-922, https://doi.org/10.1111/j.1467-6494.1996.tb00948.x.

${ }^{19}$ Caroline Bradbury-Jones and Louise Isham, "The Pandemic Paradox: The Consequences of COVID-19 on Domestic Violence," Journal of Clinical Nursing 29, no. 13-14 (2020): 2047-49, https://doi.org/10.1111/jocn.15296.
} 
and boredom. ${ }^{20}$ Homemakers may be burdened by shortages of supply and the sudden need to care for the whole family. Parents may be depressed about the future of their work and their children's education ${ }^{21}$ among all family members. It also has an impact on community family resilience.

Resilience is a concept that was initially developed in developmental psychopathology and is based on ecology, stress, and coping.22 Previous resilience studies have examined resilience in individuals, but strength itself can actually be seen in the analytical unit such as families, groups, organizations, and communities, ${ }^{23}$ positive adaptation processes accompanied by the ability to rise from bad experiences and pain. ${ }^{24}$

In the family environment, family resilience is needed, especially in this COVID-19 condition, because family resilience affects each family member's life 25 and influences and contributes to education, economy, and socialization.

\footnotetext{
${ }^{20}$ Wang et al., "Clinical Characteristics of 138 Hospitalized Patients With 2019 Novel Coronavirus-Infected Pneumonia in Wuhan, China."

${ }^{21}$ Irina Gyllenhammar et al., "Concentrations of Four New Brominated Flame Retardants (HBB, PBEB, BTBPE, DBDPE), PBDEs and HBCD in Blood Serum from First-Time Mothers in Uppsala 19962015," Digitala Vetenskapliga Arkivet (Livsmedelsverket, Uppsala, 2016), https://www.divaportal.org/smash/record.jsf?pid=diva2\%3A1052096\&dswid=-2715.

${ }^{22}$ Marty Mawarpury and Mirza Mirza, "Resiliensi dalam Keluarga: Perspektif Psikologi," Psikoislamedia: Jurnal Psikologi 2, no. 1 (2017): 96-106, https://doi.org/10.22373/psikoislamedia.
} v2i1.1829.

${ }^{23}$ Hector F. Myers and Sylvie Taylor, "Family Contributions to Risk and Resilience in African American Children," Journal of Comparative Family Studies 29, no. 1 (1998): 215-29, https://doi.org/10.3138/jcfs.29.1.215; David H. Olson, Yoav Lavee, and Hamilton I. McCubbin, "Types of Families and Family Response to Stress across the Family Life Cycle," Social Stress and Family Development, 1988, 16-43; Amanda C. Brody and Leigh Ann Simmons, "Family Resiliency During Childhood Cancer: The Father's Perspective," Journal of Pediatric Oncology Nursing 24, no. 3 (2007): 152-65, https://doi.org/10.1177/1043454206298844; Orna Cohen et al., "Family Resilience: Israeli Mothers' Perspectives," The American Journal of Family Therapy 30, no. 2 (2002): 173-87, https://doi.org/10.1080/019261802753573876.

${ }^{24}$ Jonathan A. Smith and Mike Osborn, "Pain as an Assault on the Self: An Interpretative Phenomenological Analysis of the Psychological Impact of Chronic Benign Low Back Pain," Psychology \& Health 22, no. 5 (2007): 517-34, https://doi.org/10.1080/14768320600941756; George A. Bonanno, "Loss, Trauma, and Human Resilience: Have We Underestimated the Human Capacity to Thrive After Extremely Aversive Events?," American Psychologist 59, no. 1 (2004): 20-28, https://doi.org/10.1037/0003-066X.59.1.20; Glenn E. Richardson, "The Metatheory of Resilience and Resiliency," Journal of Clinical Psychology 58, no. 3 (2002): 307-21, https://doi.org/ 10.1002/jclp.10020; S S Luthar, D Cicchetti, and B Becker, "The Construct of Resilience: A Critical Evaluation and Guidelines for Future Work., Child Development 71, no. 3 (2000): 543-62, https://doi.org/10.1111/1467-8624.00164.

${ }^{25}$ Kristen Carr, "Communication and Family Resilience," in The International Encyclopedia of Interpersonal Communication (New Jersey: Wiley, 2015), 1-9, https://doi.org/10.1002/ $9781118540190 . w b e i c 198$. 
Also, family resilience has a function to prevent the risk of problems in the family. ${ }^{26}$ Family resilience is a combination of individual characteristics, patterns of relationships, and interactions between family members so that strength is formed from strong and positive relationships in the family. ${ }^{27}$ The emergence of family resilience is based on theory and research on stress, coping, and family adaptation. ${ }^{28}$ Previous researchers began studies of family stress assuming 1) family members interact and support one another, 2) the existence of stressors requires families to adapt and make adjustments, and 3) specific rules and communities will encourage family coping and adaptation..$^{29}$

In Indonesia, family resilience is explained in Law Number 52, the Year 2009 concerning Population Development and Family Development, and Law Number 10/1992. Dynamic of a family with tenacity and resilience and contains material physical abilities and mental and spiritual spirituality to live independently, develop themselves and his family to achieve harmony in improving physical and psychological well-being.

Various factors can build family resilience during the 19th pandemic. Mackay (2003) mentions that family resilience's critical concept can be understood from three aspects: protective factors, risk factors, and vulnerability factors. McCubbin et al., ${ }^{30}$ identified family resilience factors: protective factors, recovery factors, and general family resilience factors. Family protective factors include family celebrations, family time and routine, and family traditions. Recovery factors include family integration, family support and building selfesteem, family recreation orientation, and family optimism. Meanwhile, general family resilience factors can act as protective factors and family recovery factors, including problem-solving strategies, effective communication

${ }^{26}$ Joän M. Patterson, “Understanding Family Resilience," Journal of Clinical Psychology 58, no. 3 (2002): 233-46, https://doi.org/10.1002/jclp.10019.

${ }^{27}$ Charles R. Figley and Catherine E. Burnette, "Building Bridges: Connecting Systemic Trauma and Family Resilience in the Study and Treatment of Diverse Traumatized Families," Traumatology 23, no. 1 (2017): 95-101, https://doi.org/10.1037/trm0000089.

${ }^{28}$ Sarah O. Meadows et al., "Family Resilience in the Military: Definitions, Models, and Policies," Rand Health Quarterly 5, no. 3 (2016): 12.

${ }^{29}$ William C. Nichols, "Roads to Understanding Family Resilience: 1920s to the Twenty-First Century," in Handbook of Family Resilience (New York, NY: Springer New York, 2013), 3-16, https://doi.org/10.1007/978-1-4614-3917-2_1.

${ }^{30} \mathrm{H}$. Mccubbin et al., "Families under Stress: What Makes Them Resilient," Journal of Family and Consumer Sciences, 1997. 
processes, equality, spirituality, flexibility, truth, hope, social support, and physical and emotional health. ${ }^{31}$

Family resilience is a complex process that involves social, psychological, and biological factors. There are efforts to overcome the negative consequences of oppressive events and help families and individuals adjust to life difficulties. A sign of resilience is initiative and perseverance, which are strengthened by firm hopes and beliefs. According to Julia Bryan et al. ${ }^{32}$ (quoted from Van Hook, 2008), family resilience can be realized if family members can recognize their social roles and tasks. Parents must be educated to encourage their children to engage in more creative activities, including board games, gardening, and drawing. Parents must find time to play with children and engage in daily rituals that strengthen family relationships and help spend time (WHO, 2020). Fellow family members can adequately resolve the psychological and social problems in the home during the COVID-19. Various studies on family resilience have been done quite a lot. Such as family conditions for parents who have dementia, ${ }^{33}$ family resilience to children with schizophrenia, ${ }^{34}$ and family resilience to natural hurricanes. ${ }^{35}$ But in the context of family resilience during the COVID-19 pandemic, there are still not many. This research focuses on the level of family resilience during the COVID-19 pandemic in the red zone in several aspects. This study's results can also be the basis for understanding, preventing, and dealing with the impact of COVID-19 on family resilience.

\footnotetext{
${ }^{31}$ Elma Kaiser and Allison N Sinanan, "Survival and Resilience of Female Street Children Experiencing Sexual Violence in Bangladesh: A Qualitative Study," Journal of Child Sexual Abuse 29, no. 5 (2020): 550-69, https://doi.org/10.1080/10538712.2019.1685615.

32Julia Bryan et al., "Social Capital and College-Going Culture in High Schools: The Effects of College Expectations and College Talk on Students' Postsecondary Attendance," Professional School Counseling 21, no. 1 (2017): 95-107, https://doi.org/10.5330/1096-2409-21.1.95.

${ }^{33}$ Melanie Deist and Abraham P. Greeff, "Resilience in Families Caring for a Family Member Diagnosed with Dementia," Educational Gerontology 41, no. 2 (2015): 93-105, https://doi.org/ 10.1080/03601277.2014.942146.

${ }^{34}$ M. Bishop and A. P. Greeff, "Resilience in Families in Which a Member Has Been Diagnosed with Schizophrenia," Journal of Psychiatric and Mental Health Nursing 22, no. 7 (2015): 463-71, https://doi.org/10.1111/jpm.12230.

${ }^{35}$ Catherine E McKinley et al., "Hurricanes and Indigenous Families: Understanding Connections with Discrimination, Social Support, and Violence on PTSD," Journal of Family Strengths 19, no. 1 (2019): 10.
} 


\section{B. Method}

This research was conducted on the people who live in the COVID-19 red zone area at Jabodetabek area, with a total sample of 311 people. Sampling was obtained by using the convenience sampling method. This research uses a quantitative approach with descriptive research methods. ${ }^{36}$ The data in this study were political data collected using the Family Resilience instrument distributed using the Google Form application with four alternative answers in the Likert scale model among the choices of solutions are 1) Always, 2) Often, 3) Sometimes and 4) Never.

The instrument in this study is based on six indicators: 1) Positive outlook, 2) Spirituality, 3) Communication in the family, 4) Engagement in the family, 5) Financial Management, and 6) Social Support. This study uses a quantitative approach. The data analysis technique used is descriptive statistics using the SPSS application combined with Rasch Modeling analysis using the Winsteps application. ${ }^{37}$

\section{Results}

The results are discussed in detail based on the SPSS and the Rasch Model analysis. It addresses several items, including the level of family resilience in the red zone areas affected by COVID-19. The study results and interpretation of family endurance are seen based on scalograms, analysis of answer patterns on family endurance tests is presented with good validity.

Table 1 shows the categorization of family endurance tests in the COVID19 red zone area. Table 1 shows that family resilience in the red zone affected

\footnotetext{
36John W Creswell, Research Design: Qualitative, Quantitative, and Mixed Methods Approaches (New York: SAGE Publications, 2017); Zoltan Dornyei, Research Methods in Applied Linguistics: Quantitative, Qualitative, and Mixed Methodologies (Oxford: Oxford University Press, 2007); K. McCusker and S. Gunaydin, "Research Using Qualitative, Quantitative or Mixed Methods and Choice Based on the Research," Perfusion 30, no. 7 (2015): 537-42, https://doi.org/10.1177/ 0267659114559116; A. Muri Yusuf, Metode Penelitian Kuantitatif, Kualitatif \& Penelitian Gabungan (Jakarta: Prenada Media, 2016).

${ }^{37}$ Trevor Bond, Zi Yan, and Moritz Heene, Applying the Rasch Model, Fundamentals Measurement in the Human Science, 3rd ed. (New York: Routledge, 2015); John M. Linacre, "A User's Guide to WINSTEPS Ministeps Rasch-Model Computer Programs" (winsteps.com, 2011); B. Sumintono and W. Widhiarso, Aplikasi Pemodelan Rasch Pada Assessment Pendidikan (Bandung: Trim Komunikata, 2015).
} 
by COVID-19 is in the medium category with a percentage of $68.9 \%$. This analysis supports the observations that there are still some that are less serious and do not think deeply. The results of the study below support this.

Table 1.

Categorization of Family Resilience

\begin{tabular}{lrrrr}
\hline & \multicolumn{4}{c}{ NP } \\
\cline { 2 - 5 } Level & Frequency & Percent & $\begin{array}{r}\text { Valid } \\
\text { Percent }\end{array}$ & $\begin{array}{r}\text { Cumulative } \\
\text { Percent }\end{array}$ \\
\hline Rendah & 46 & 14.7 & 14.7 & 14.7 \\
Sedang & 215 & 68.9 & 68.9 & 83.7 \\
Tinggi & 51 & 16.3 & 16.3 & 100.0 \\
\hline Total & 312 & 100.0 & 100.0 & \\
\hline
\end{tabular}

Table 2.

Baseline Data from Six Indicators of Family Resilience

\begin{tabular}{lcrrr}
\hline \multirow{2}{*}{ Indicator } & \multicolumn{4}{c}{ Descriptive Statistics } \\
& Min & Max & Mean & Std. Deviation \\
\hline Positive Outlook & 7 & 20 & 16.79 & 2.69 \\
Spirituality & 6 & 16 & 13.36 & 2.12 \\
Communication in the family & 6 & 16 & 12.82 & 2.12 \\
Attachment in the family & 7 & 24 & 18.33 & 3.18 \\
Financial Management & 3 & 12 & 8.19 & 1.91 \\
Social Support & 4 & 8 & 7.21 & 1.02 \\
\hline
\end{tabular}

In the Figure 1, it can be seen that there are 95 respondents (top) having respondents who are not fit compared to the others, as well as 23 and 41 . Furthermore, it can be interpreted that respondents who have the highest family security are respondents with numbers 109 and 132. Again, the lowest value is in unpluralize. The level of family resilience is in the moderate position with a percentage of $68.9 \%$. The results of the validity and reliability analysis are explained in the figure 2. 
Dony Darma Sagita, Mutiara Felicita Amsal, Shafna Utami Nur Fairuz

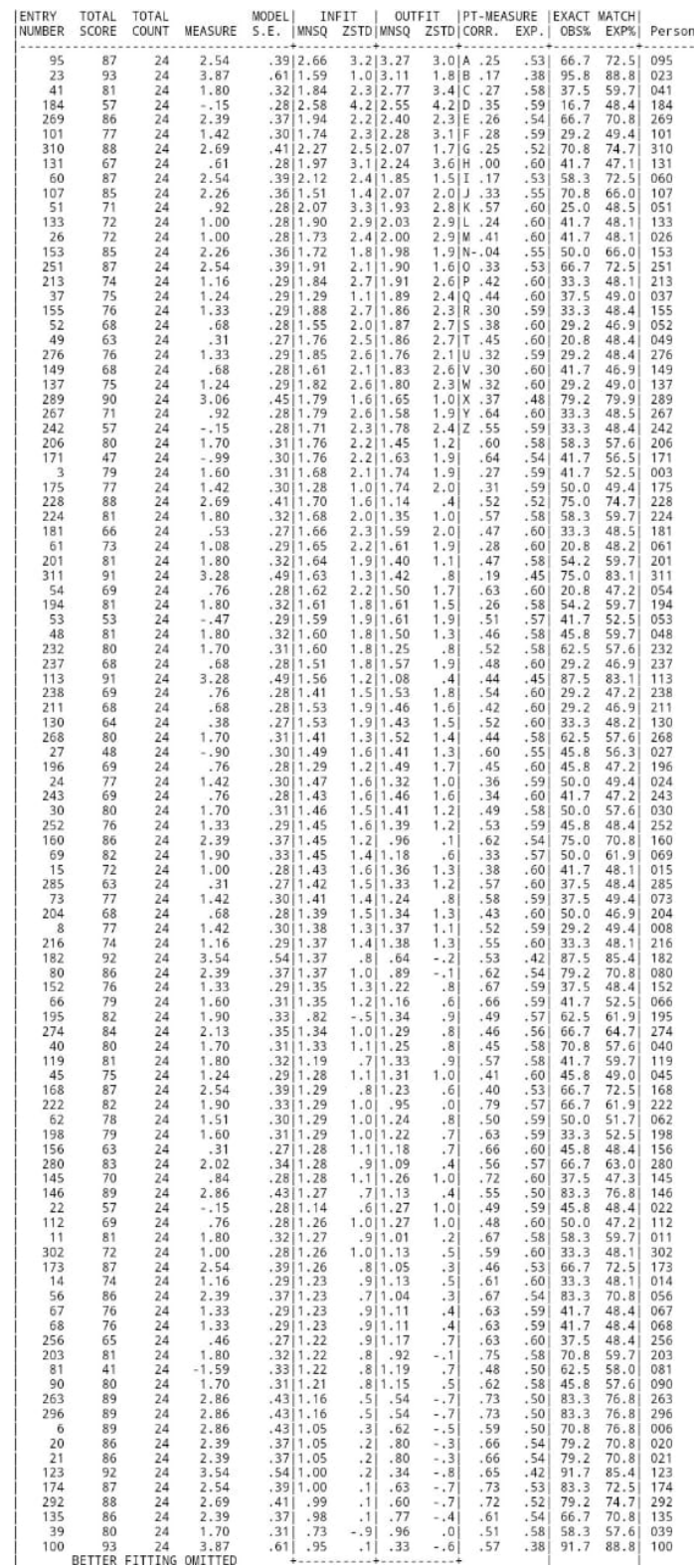

Figure 1.

Person Statistic: Misfit Order 
SUMMARY OF 311 MEASURED (NON-EXTREME) Person

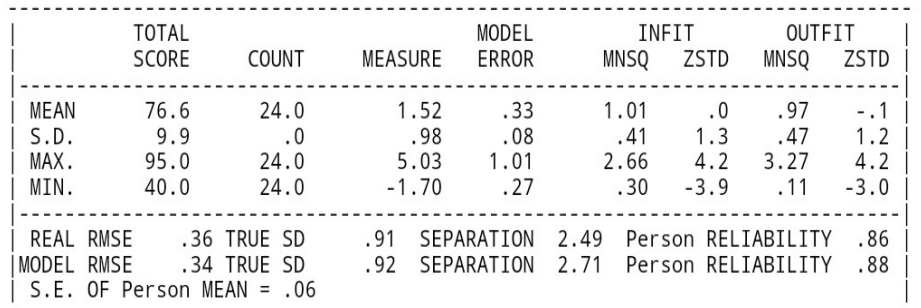

Figure 2.

Summary Statistic Measured Person

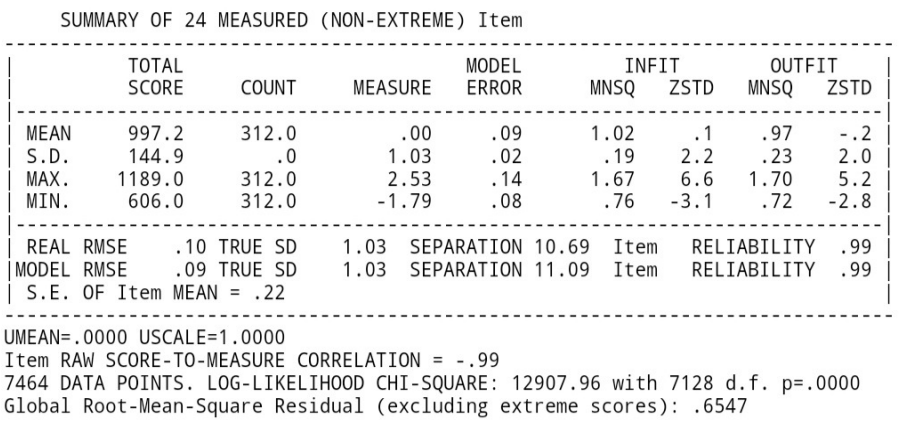

Figure 3.

Summary Statistic Measured Item

Figure 2 shows that the mean value of a person is (1.52 logit> 0.00 logit), which means that respondents' tendency to answer more is always the instrument that has been given to see the extent of family resilience. ${ }^{38}$ The reliability of respondents shows the number 0.86 , which means respondents' consistency in answering choices on the instrument shows good. ${ }^{39}$ The interaction between the item and person reliability values of 0.89 means that

38Linacre, "A User's Guide to WINSTEPS Ministeps Rasch-Model Computer Programs."

${ }^{39}$ Sumintono and Widhiarso, Aplikasi Pemodelan Rasch Pada Assessment Pendidikan; Bond, Yan, and Heene, Applying the Rasch Model, Fundamentals Measurement in the Human Science. 
the alpha Cronbach's quality is classified as excellent quality. Also, the sensitivity value for person answers is +1.01 Logit (INFIT MNSQ), and the sensitivity value for person answers as a whole is +0.97 Logit (OUTFIT MNSQ) which means that it is still in the ideal range $(+0.5>$ MNSQ $<+1,5) .{ }^{40}$ In the grouping section, people get four results which means that there are four groups of respondents.

Furthermore, Figure 3 shows that the instrument's reliability is (0.99), meaning that its quality is in an outstanding category. Besides, the item answer's sensitivity value is +1.02 logit, and the overall value of the item answer sensitivity is +0.97 logit. This indicates that it is still in the ideal range. This shows that the instrument's things are of good quality for the conditions of measurement that have been done.

Figure 4 shows that the natural variance is $48 \%$, not so much different from the expected value of $48.9 \%$. This indicates that the $20 \%$ one-dimensional minimum requirements have been met. 41 The results of unexpended $1-5$, it is $9 \%$ which shows an adequate level of instrument. Thus this condition states that the one-dimensional requirements of the instrument can be fulfilled. Also, $t$ is noted that the 24 items used are valid.

\begin{tabular}{|c|c|c|c|c|c|}
\hline & & - Em & pirica. & - & Modele \\
\hline Total raw variance in observations & $=$ & 46.1 & $100.0 \%$ & & $100.0 \%$ \\
\hline Raw variance explained by measures & $=$ & 22.1 & $48.0 \%$ & & \\
\hline Raw variance explained by persons & $=$ & 8.9 & $19.3 \%$ & & \\
\hline Raw Variance explained by items & $=$ & 13.2 & $28.7 \%$ & & \\
\hline Raw unexplained variance (total) & $=$ & 24.0 & $52.0 \%$ & $100.0 \%$ & 51. \\
\hline Unexplned variance in 1st contrast & $=$ & 2.3 & $5.1 \%$ & $9.7 \%$ & \\
\hline Unexplned variance in 2nd contrast & $=$ & 1.9 & $4.2 \%$ & $8.1 \%$ & \\
\hline Unexplned variance in $3 \mathrm{rd}$ contrast & $=$ & 1.7 & $3.7 \%$ & $7.2 \%$ & \\
\hline Unexplned variance in 4 th contrast & $=$ & 1.5 & $3.2 \%$ & $6.2 \%$ & \\
\hline Unexplned variance in 5th contrast & $=$ & 1.4 & $3.0 \%$ & $5.8 \%$ & \\
\hline
\end{tabular}

Figure 4.

Standardized Residual Variance

\footnotetext{
${ }^{40}$ Trevor Bond and Christine M. Fox, Applying the Rasch Model: Fundamental Measurement in the Human Sciences (New Jersey: Routledge, 2015), https://doi.org/10.4324/9781315814698.

${ }^{41}$ Linacre, "A User's Guide to WINSTEPS Ministeps Rasch-Model Computer Programs."
} 


\section{Discussion}

The study results showed that the level of family resilience in the red zone affected by COVID-19 is divided into three categories: high, medium, and low. The work shows that the level of family resilience in the moderate categorization is $16 \%, 16.3 \%$ for the high category, and $14.7 \%$ for the low class. This means that the family's condition in the red zone is sufficient to survive in difficult situations of life and adapt to these conditions and rise from adversity. The indicators reinforce this on family resilience which shows that attachment in the family has an essential role with a score of $18.33 \%$. It is believed that the passion between members is able to solve a problem that occurs so that they can work together to recover from a situation. The same thing is expressed that attachment to each other can make the family able to coordinate with bai, attract each other from adversity, and significantly impact recovery. ${ }^{42}$

Furthermore, a positive outlook with a score of $16.79 \%$ indicates that a positive outlook can strengthen one another and be able to rise from adversity. Positive emotions can be in the form of my love, humor, optimism, having positive solutions and suggestions that strengthen one another will make the family stronger. ${ }^{43}$ Families who have a positive perspective will see the difficulties faced as a challenge that can be passed together and make it an experience and life process that must be accepted. This finding is also in line with research conducted by Siahaan that festive desserts can strengthen them and become a motivator to continue to work to overcome problems, and is confident that things will get better in the future. ${ }^{44}$

Furthermore, spiritual indicators with a score of $13.36 \%$ adopted by a family are felt to provide suggestions for positive solutions to problems experienced by families. ${ }^{45}$ The emergence of COVID-19 teaches that material is not everything. It starts to improve the quality of worship by always getting closer to God, such as listening to studies or lectures, worshiping in the

\footnotetext{
${ }^{42}$ Jorge M Lobo et al., "KnowBR: An Application to Map the Geographical Variation of Survey Effort and Identify Well-Surveyed Areas from Biodiversity Databases," Ecological Indicators 91 (2018): 241-48, https://doi.org/10.1016/j.ecolind.2018.03.077.

${ }^{43}$ Lobo etal.

44Rondang Siahaan, "Ketahanan Sosial Keluarga: Perspektif Pekerjaan Sosial," Sosio Informa 17, no. 2 (2012): 82-96, https://doi.org/10.33007/inf.v17i2.95.

${ }^{45}$ Emily Padgett et al., "Marital Sanctification and Spiritual Intimacy Predicting Married Couples' Observed Intimacy Skills across the Transition to Parenthood," Religions 10, no. 3 (2019): 177, https://doi.org/10.3390/rel10030177.
} 
congregation, and other activities aimed at improving spirituality. The results are strengthened by an explanation conducted by Canda and Furman, who states that spirituality is the heart of help, empathy, and attention, and how people view and experience life's events. ${ }^{46}$

Communication in the family falls into the score of $12.82 \%$. Communication patterns are essential for family resilience both verbally and nonverbally; the designs must be reciprocated with each other so that communication can go well. Communication can be complicated if not giving and receiving, which results in misunderstanding, feeling unappreciated, feeling poorly understood, making it a problem between family members that makes communication unhealthy. The next indicator is financial management with a score of $8.19 \%$ and social support $7.21 \%$; both of these points are in a low position compared to other indicators; during the COVID-19 pandemic period, the economy is hampered, which family members who have jobs forced not to work, because following the call to not do activities outside the home. The low social support experienced in the red zone region resulted in family resilience in the moderate category.

The instrument test results using Rasch show that the instrument is in the outstanding category with a reliability value $(0.99)$. The item sensitivity value is +1.02 logit, and the overall score is +0.971 logit.

\section{E. Conclusion}

The study results showed that the level of family resilience in the red zone affected by COVID-19 is divided into three categories: high, medium, and low. The work shows that the level of family resilience in the moderate categorization is $16 \%, 16.3 \%$ for the high category, and $14.7 \%$ for the low class. This means that the family's condition in the red zone is sufficient to survive in difficult situations of life and adapt to these conditions and rise from adversity. The indicators reinforce this on family resilience which shows that the family's attachment has an essential role with $18.33 \%$. It is believed that the passion between members is able to solve a problem that occurs so that they can work together to recover from a situation.

${ }^{46}$ Eward R. Canda and Leola Dyrud Furman, Spiritual Diversity in Social Work Practice: The Heart of Helping (New York: Oxford University Press, 2010); Kelsey M. Moffatt and Holly K. Oxhandler, "Religion and Spirituality in Master of Social Work Education: Past, Present, and Future Considerations,” Journal of Social Work Education 54, no. 3 (2018): 543-53, https://doi.org/ 10.1080/10437797.2018.1434443. 
Furthermore, a positive outlook with a score of $16.79 \%$ indicates that a positive outlook can strengthen one another and rise from adversity. A spiritual indicator with a score of $13.36 \%$ adopted by a family is felt to provide positive solutions to problems experienced by the family. Communication in the family with $12.82 \%$ communication patterns is essential for family resilience both verbally and non-verbally; the designs must be reciprocated so that communication can go well. financial management with a score of $8.19 \%$ and social support $7.21 \%$, both of these points are in a low position compared to other indicators; during the COVID-19 pandemic period, the economy was hampered, which family members who had jobs were forced not to work because following the call to not do activities outside the home and the low social support experienced in the red zone resulted in the resilience of the family is in the medium category.[s]

\section{References}

Abebe, Gedif Meseret. "Emerging and Re-Emerging Viral Diseases: The Case of Coronavirus Disease-19 (COVID-19)." International Journal of Virology and AIDS 7 (2020): 067.https://doi.org/10.23937/2469-567X/1510067.

Affleck, Glenn, and Howard Tennen. "Construing Benefits from Adversity: Adaptotional Significance and Dispositional Underpinnings." Journal of Personality 64, no. 4 (1996): 899-922.https://doi.org/10.1111/j.1467-6494.1996.tb00948.x.

Alvian, Yusak, and Steven Laudry. "Propaganda COVID-19 terhadap Awareness Masyarakat Surabaya untuk Mengikuti Program Kerja Pemerintah." Jurnal Komunikasi Profesional 4, no. 1 (2020): 27-41. https://doi.org/10.25139/ jkp.v4i1.2569.

Bhat, Ritesh, Varun Kumar Singh, Nithesh Naik, C Raghavendra Kamath, Prashant Mulimani, and Niranjan Kulkarni. "COVID 2019 Outbreak: The Disappointment in Indian Teachers." Asian Journal of Psychiatry 50 (2020): 102047. https://doi.org/ 10.1016/j.ajp.2020.102047.

Bishop, M., and A. P. Greeff. "Resilience in Families in Which a Member Has Been Diagnosed with Schizophrenia." Journal of Psychiatric and Mental Health Nursing 22, no. 7 (2015): 463-71. https://doi.org/10.1111/jpm.12230.

Bonanno, George A. "Loss, Trauma, and Human Resilience: Have We Underestimated the Human Capacity to Thrive After Extremely Aversive Events?" American Psychologist 59, no. 1 (2004): 20-28. https://doi.org/10.1037/0003-066X. 59.1.20. 
Bond, Trevor, and Christine M. Fox. Applying the Rasch Model: Fundamental Measurement in the Human Sciences. New Jersey: Routledge, 2015. https://doi.org/10.4324/9781315814698.

Bond, Trevor, Zi Yan, and Moritz Heene. Applying the Rasch Model, Fundamentals Measurement in the Human Science. 3rd ed. New York: Routledge, 2015.

Bradbury-Jones, Caroline, and Louise Isham. "The Pandemic Paradox: The Consequences of COVID-19 on Domestic Violence." Journal of Clinical Nursing 29, no. 13-14 (2020): 2047-49. https://doi.org/10.1111/jocn.15296.

Brody, Amanda C., and Leigh Ann Simmons. "Family Resiliency During Childhood Cancer: The Father's Perspective." Journal of Pediatric Oncology Nursing 24, no. 3 (2007): 152-65. https://doi.org/10.1177/1043454206298844.

Bryan, Julia, Raquel Farmer-Hinton, Anita Rawls, and Chenoa S. Woods. "Social Capital and College-Going Culture in High Schools: The Effects of College Expectations and College Talk on Students' Postsecondary Attendance." Professional School Counseling 21, no. 1 (2017): 95-107. https://doi.org/10.5330/1096-240921.1.95.

Canda, Eward R., and Leola Dyrud Furman. Spiritual Diversity in Social Work Practice: The Heart of Helping. New York: Oxford University Press, 2010.

Carr, Kristen. "Communication and Family Resilience." In The International Encyclopedia of Interpersonal Communication, 1-9. New Jersey: Wiley, 2015. https://doi.org/10.1002/9781118540190.wbeic198.

Cohen, Orna, Iris Slonim, Ricky Finzi, and Ronit D. Leichtentritt. "Family Resilience: Israeli Mothers' Perspectives." The American Journal of Family Therapy 30, no. 2 (2002): 173-87. https://doi.org/10.1080/019261802753573876.

Creswell, John W. Research Design: Qualitative, Quantitative, and Mixed Methods Approaches. New York: SAGE Publications, 2017.

Dani, Jeratallah Aram, and Yogi Mediantara. "COVID-19 dan Perubahan Komunikasi Sosial." Persepsi: Communication Journal 3, no. 1 (2020): 94-102. https://doi.org/ 10.30596/persepsi.v3i1.4510.

Deist, Melanie, and Abraham P. Greeff. "Resilience in Families Caring for a Family Member Diagnosed with Dementia." Educational Gerontology 41, no. 2 (2015): 93-105. https://doi.org/10.1080/03601277.2014.942146.

Dong, Lu, and Jennifer Bouey. "Public Mental Health Crisis during COVID-19 Pandemic, China.” Emerging Infectious Diseases 26, no. 7 (2020): 1616-18. https://doi.org/ 10.3201/eid2607.202407.

Dornyei, Zoltan. Research Methods in Applied Linguistics: Quantitative, Qualitative, and Mixed Methodologies. Oxford: Oxford University Press, 2007. 
Figley, Charles R., and Catherine E. Burnette. "Building Bridges: Connecting Systemic Trauma and Family Resilience in the Study and Treatment of Diverse Traumatized Families." Traumatology 23, no. 1 (2017): 95-101. https://doi.org/ 10.1037/trm0000089.

Folkman, Susan, and Judith Tedlie Moskowitz. "Positive Affect and the Other Side of Coping." American Psychologist 55, no. 6 (2000): 647-54. https://doi.org/ 10.1037/0003-066X.55.6.647.

Gyllenhammar, Irina, Anders Glynn, Tatiana Cantillana, Marie Aune, Per Ola Darnerud, and Sanna Lignell. "Concentrations of Four New Brominated Flame Retardants (HBB, PBEB, BTBPE, DBDPE), PBDEs and HBCD in Blood Serum from First-Time Mothers in Uppsala 1996-2015." Digitala Vetenskapliga Arkivet. Livsmedelsverket, Uppsala, 2016. https://www.diva-portal.org/smash/record. jsf?pid=diva2\%3A1052096\&dswid=-2715.

Hadiwardoyo, Wibowo. "Kerugian Ekonomi Nasional Akibat Pandemi COVID-19." Baskara Journal of Business and Enterpreneurship 2, no. 2 (2020): 83-92. https://doi.org/10.24853/baskara.2.2.83-92.

Hairunisa, Nany, and Husnun Amalia. "Review: Penyakit Virus Corona Baru 2019 (COVID-19)." Jurnal Biomedika dan Kesehatan 3, no. 2 (2020): 90-100. https://doi.org/10.18051/JBiomedKes.2020.v3.90-100.

Halim, Devina. "Rp 72 Miliar untuk Influencer dalam Atasi Dampak Virus Corona, Pengamat: Mau Diapain?" Kompas, March 2, 2020. https://nasional.kompas. com/read/2020/03/02/10323441/rp-72-miliar-untuk-influencer-dalam-atasidampak-virus-corona-pengamat-mau?page=all.

Hasrul, Muh. "Aspek Hukum Pemberlakuan Pembatasan Sosial Berskala Besar (PSBB) Dalam Rangka Penanganan Corona Virus Disease 2019 (COVID-19)." Legislatif 3, no. 2 (2020): 385-98.

Ho, Cyrus Sh, Cornelia Yi Chee, and Roger Cm Ho. "Mental Health Strategies to Combat the Psychological Impact of COVID-19 Beyond Paranoia and Panic." Annals of the Academy of Medicine, Singapore 49, no. 3 (2020): 155-60.

Kaiser, Elma, and Allison N Sinanan. "Survival and Resilience of Female Street Children Experiencing Sexual Violence in Bangladesh: A Qualitative Study." Journal of Child Sexual Abuse 29, no. 5 (2020): 550-69. https://doi.org/10.1080/10538712.2019. 1685615.

Lai, Chih-Cheng, Tzu-Ping Shih, Wen-Chien Ko, Hung-Jen Tang, and Po-Ren Hsueh. "Severe Acute Respiratory Syndrome Coronavirus 2 (SARS-CoV-2) and Coronavirus Disease-2019 (COVID-19): The Epidemic and the Challenges." International Journal of Antimicrobial Agents 55, no. 3 (2020): 105924. https://doi.org/10.1016/j.ijantimicag.2020.105924. 
Linacre, John M. "A User's Guide to WINSTEPS Ministeps Rasch-Model Computer Programs." winsteps.com, 2011.

Liu, Jia Jia, Yanping Bao, Xiaolin Huang, Jie Shi, and Lin Lu. "Mental Health Considerations for Children Quarantined Because of COVID-19." The Lancet Child \& Adolescent Health 4, no. 5 (2020): 347-49. https://doi.org/10.1016/S23524642(20)30096-1.

Lobo, Jorge M, Joaquín Hortal, José Luís Yela, Andrés Millán, David Sánchez-Fernández, Emilio García-Roselló, Jacinto González-Dacosta, Juergen Heine, Luís GonzálezVilas, and Castor Guisande. "KnowBR: An Application to Map the Geographical Variation of Survey Effort and Identify Well-Surveyed Areas from Biodiversity Databases." Ecological Indicators 91 (2018): 241-48. https://doi.org/10.1016/ j.ecolind.2018.03.077.

Luthar, S S, D Cicchetti, and B Becker. "The Construct of Resilience: A Critical Evaluation and Guidelines for Future Work." Child Development 71, no. 3 (2000): 543-62. https://doi.org/10.1111/1467-8624.00164.

Mawarpury, Marty, and Mirza Mirza. "Resiliensi dalam Keluarga: Perspektif Psikologi." Psikoislamedia: Jurnal Psikologi 2, no. 1 (2017): 96-106. https://doi.org/ 10.22373/psikoislamedia.v2i1.1829.

Mccubbin, H., M. McCubbin, A. Thompson, S. Han, and Chad T. Allen. "Families under Stress: What Makes Them Resilient." Journal of Family and Consumer Sciences, 1997.

McCusker, K., and S. Gunaydin. "Research Using Qualitative, Quantitative or Mixed Methods and Choice Based on the Research." Perfusion 30, no. 7 (2015): 537-42. https://doi.org/10.1177/0267659114559116.

McKinley, Catherine E, Jenn Miller Scarnato, Jessica Liddell, Hannah Knipp, and Shanondora Billiot. "Hurricanes and Indigenous Families: Understanding Connections with Discrimination, Social Support, and Violence on PTSD." Journal of Family Strengths 19, no. 1 (2019): 10.

Meadows, Sarah O., Megan K. Beckett, Kirby Bowling, Daniela Golinelli, Michael P. Fisher, Laurie T. Martin, Lisa S. Meredith, and Karen Chan Osilla. "Family Resilience in the Military: Definitions, Models, and Policies." Rand Health Quarterly 5, no. 3 (2016): 12.

Moffatt, Kelsey M., and Holly K. Oxhandler. "Religion and Spirituality in Master of Social Work Education: Past, Present, and Future Considerations." Journal of Social Work Education 54, no. 3 (2018): 543-53. https://doi.org/10.1080/10437797.2018. 1434443.

Myers, Hector F., and Sylvie Taylor. "Family Contributions to Risk and Resilience in African American Children." Journal of Comparative Family Studies 29, no. 1 (1998): 215-29. https://doi.org/10.3138/jcfs.29.1.215. 
Nichols, William C. "Roads to Understanding Family Resilience: 1920s to the TwentyFirst Century." In Handbook of Family Resilience, 3-16. New York, NY: Springer New York, 2013. https://doi.org/10.1007/978-1-4614-3917-2_1.

Olson, David H., Yoav Lavee, and Hamilton I. McCubbin. "Types of Families and Family Response to Stress across the Family Life Cycle." Social Stress and Family Development, 1988, 16-43.

Padgett, Emily, Annette Mahoney, Kenneth Pargament, and Alfred DeMaris. "Marital Sanctification and Spiritual Intimacy Predicting Married Couples' Observed Intimacy Skills across the Transition to Parenthood." Religions 10, no. 3 (2019): 177. https://doi.org/10.3390/rel10030177.

Pakpahan, Aknolt Kristian. "COVID-19 dan Implikasi bagi Usaha Mikro, Kecil, dan Menengah." Jurnal Ilmiah Hubungan Internasional 16, no. 1 (2020): 59-64. https://doi.org/10.26593/jihi.v0i0.3870.59-64.

Patterson, Joän M. “Understanding Family Resilience." Journal of Clinical Psychology 58, no. 3 (2002): 233-46. https://doi.org/10.1002/jclp.10019.

Radhitya, Theresia Vania, Nunung Nurwati, and Maulana Irfan. "Dampak Pandemi COVID-19 terhadap Kekerasan dalam Rumah Tangga." Jurnal Kolaborasi Resolusi Konflik2, no. 2 (2020): 111-19. https://doi.org/10.24198/jkrk.v2i2.29119.

Restuningdyah, Novia Andansari Putri, and Emmy Amalia. "Pemeriksaan CT-SCAN Thorax pada Kasus Covid-19 di Provinsi Nusa Tenggara Barat." Jurnal Pengabdian Magister IPA 3, no. 1 (2020): 1-4. https://doi.org/10.29303/ jpmpi.v3i1.447.

Richardson, Glenn E. "The Metatheory of Resilience and Resiliency." Journal of Clinical Psychology58, no. 3 (2002): 307-21. https://doi.org/10.1002/jclp.10020.

Sadhu, Soumen, Rupesh Agrawal, Richa Pyare, Carlos Pavesio, Manfred Zierhut, Anadi Khatri, Justine R. Smith, Marc D. de Smet, and Jyotirmay Biswas. "COVID-19: Limiting the Risks for Eye Care Professionals." Ocular Immunology and Inflammation 28, no. 5 (2020): 714-20. https://doi.org/10.1080/09273948. 2020.1755442.

Siahaan, Rondang. "Ketahanan Sosial Keluarga: Perspektif Pekerjaan Sosial." Sosio Informa 17, no. 2 (2012): 82-96. https://doi.org/10.33007/inf.v17i2.95.

Smith, Jonathan A., and Mike Osborn. "Pain as an Assault on the Self: An Interpretative Phenomenological Analysis of the Psychological Impact of Chronic Benign Low Back Pain." Psychology \& Health 22, no. 5 (2007): 517-34. https://doi.org/ 10.1080/14768320600941756.

Statistics Canada. "Canadian Perspectives Survey Series 1: Impacts of COVID-19." Canada, April 8, 2020. https://www150.statcan.gc.ca/n1/daily-quotidien/ 200408/dq200408c-eng.htm. 
Sumintono, B., and W. Widhiarso. Aplikasi Pemodelan Rasch pada Assessment Pendidikan. Bandung: Trim Komunikata, 2015.

Suni, Nur Sholikah Putri. "Kesiapsiagaan Indonesia Menghadapi Potensi Penyebaran Corona." Pusat Penelitian Badan Keahlian DPR RI, 2020. http://sdip.dpr.go.id/ search/detail/category/Info Singkat/id/1033.

Susanto, Nugroho. "Pengaruh Virus COVID-19 terhadap Bidang Olah Raga di Indonesia." Jurnal Stamina 3, no. 3 (2020): 145-53. https://doi.org/10.24036/ jst.v3i3.491.

Tanoue, Yuta, Shuhei Nomura, Daisuke Yoneoka, Takayuki Kawashima, Akifumi Eguchi, Shoi Shi, Nahoko Harada, and Hiroaki Miyata. "Mental Health of Family, Friends, and Co-Workers of COVID-19 Patients in Japan." Psychiatry Research 291 (2020): 113067.https://doi.org/10.1016/j.psychres.2020.113067.

Wang, Dawei, Bo Hu, Chang Hu, Fangfang Zhu, Xing Liu, Jing Zhang, Binbin Wang, et al. "Clinical Characteristics of 138 Hospitalized Patients With 2019 Novel Coronavirus-Infected Pneumonia in Wuhan, China." JAMA 323, no. 11 (2020): 1061. https://doi.org/10.1001/jama.2020.1585.

World Health Organization. "WHO Director-General's Opening Remarks at the Media Briefing on COVID-19-11 March 2020." Geneva, Switzerland, 2020. https://www.who.int/director-general/speeches/detail/who-director-generals-opening-remarks-at-the-media-briefing-on-covid-19---11-march-2020.

Yoon, Mi-Kyung, Soon-Young Kim, Hye-Sun Ko, and Myung-Soo Lee. "System Effectiveness of Detection, Brief Intervention and Refer to Treatment for the People with Post-Traumatic Emotional Distress by MERS: A Case Report of Community-Based Proactive Intervention in South Korea." International Journal of Mental Health Systems 10, no. 1 (2016): 51. https://doi.org/10.1186/s13033016-0083-5.

Yunus, Nur Rohim, and Annissa Rezki. "Kebijakan Pemberlakuan Lock Down Sebagai Antisipasi Penyebaran Corona Virus Covid-19." Salam: Jurnal Sosial dan Budaya Syar'i 7, no. 3 (2020): 227-38. https://doi.org/10.15408/sjsbs.v7i3.15083.

Yusuf, A. Muri. Metode Penelitian Kuantitatif, Kualitatif \& Penelitian Gabungan. Jakarta: Prenada Media, 2016.

Zowalaty, Mohamed E El, and Josef D Järhult. "From SARS to COVID-19: A Previously Unknown SARS- Related Coronavirus (SARS-CoV-2) of Pandemic Potential Infecting Humans - Call for a One Health Approach." One Health 9 (2020): 100124. https://doi.org/10.1016/j.onehlt.2020.100124. 